\title{
Communication and validation of metrological smart data in IoT-networks
}

\author{
Ačko, B. ${ }^{a,}{ }^{,}$, Weber, H. ${ }^{b}$, Hutzschenreuter, D. ${ }^{b}$, Smith, I. ${ }^{c}$ \\ a University of Maribor, Faculty of Mechanical Engineering, Maribor, Slovenia \\ ${ }^{\mathrm{b}}$ Physikalisch-Technische Bundesanstalt, Braunschweig, Germany \\ ${ }^{c}$ National Physical Laboratory, Teddington, United Kingdom
}

\begin{abstract}
A B S TRACT
An Internet of Things-network (IoT- network) allows for the communication of data both within the network and to data hubs. However, the usefulness of the data depends on its ability to be interpreted correctly. For metrology data, effective use of the data is only possible if the numerical value, associated unit and uncertainty, expressed in a standard format, are also available. In order to develop, provide and distribute a formal framework for the transmission of metrology data on the basis of the International System of Units, European project EMPIR 17IND02 SmartCom was agreed between the European Commission and the European Association of National Metrology Institutes (Euramet). The SmartCom project aims to provide the methodological and technical foundation for the unambiguous, universal, safe and uniform communication of metrological smart data in the IoT and Industry 4.0. The project will increase the industrial capabilities and the provision of regulations for data exchange in the IoT. It will also assist countries within the European Union (EU) and those with an association agreement with the EU in developing products that are able to communicate in IoT environments worldwide. In addition to describing the general ideas and aims of the project, this article presents the research results achieved in the first midterm period.
\end{abstract}

(c) $2020 \mathrm{CPE}$, University of Maribor. All rights reserved.

\author{
ARTICLE INFO \\ Keywords: \\ Metrology; \\ Measurement metadata; \\ Information and communication \\ technology (ICT); \\ Smart Data; \\ Data communication; \\ IoT-communication; \\ IoT-networking; \\ Digital calibration certificate \\ *Corresponding author: \\ bojan.acko@um.si \\ (Ačko, B) \\ Article history: \\ Received 27 December 2019 \\ Revised 26 March 2020 \\ Accepted 28 March 2020
}

\section{References}

[1] Gajsek, B., Marolt, J., Rupnik, B., Lerher, T., Sternad, M. (2019). Using maturity model and discrete-event simulation for Industry 4.0 implementation, International Journal of Simulation Modelling, Vol. 18, No. 3, 488-499, doi: 10.2507/IJSIMM18(3)489.

[2] Vieira, A.A.C., Dias, L.M.S., Santos, M.Y., Pereira, G.A.B., Oliveira, J.A. (2018). Setting an Industry 4.0 research and development agenda for simulation - A literature review, International Journal of Simulation Modelling, Vol. 17, No. 3, 377-390, doi: 10.2507/IJSIMM17(3)429.

[3] Resman, M., Pipan, M., Šimic, M., Herakovič, N. (2019). A new architecture model for smart manufacturing: A performance analysis and comparison with the RAMI 4.0 reference model, Advances in Production Engineering \& Management, Vol. 14, No. 2, 153-165, doi: 10.14743/apem2019.2.318.

[4] Vujica Herzog, N., Buchmeister, B., Beharic, A., Gajsek, B. (2018). Visual and optometric issues with smart glasses in Industry 4.0 working environment, Advances in Production Engineering \& Management, Vol. 13, No. 4, 417428, doi: $10.14743 /$ apem2018.4.300.

[5] JCGM 200:2012 (2012). International vocabulary of metrology - Basic and general concepts and associated terms (VIM), $3^{\text {rd }}$ edition, 2008 version with minor corrections, from https://www.bipm.org/en/publications/guides/, accessed November 8, 2019.

[6] Euramet (2008). Metrology - in short, 3rd edition, from https://www.euramet.org/publications-media-centre/ documents/metrology-in-short/, accessed November 18, 2019. 
[7] JCGM 100:2008 (2008). Evaluation of measurement data - Guide to the expression of uncertainty in measurement, $1^{\text {st }}$ edition, from https://www.bipm.org/en/publications/guides/ accessed October 21, 2019.

[8] BIPM (2019). The international system of units (SI), 9 $9^{\text {th }}$ edition, from https://www.bipm.org/en/publications/sibrochure/, accessed November 8, 2019.

[9] Thompson A., Taylor, B.N. (2008). Guide for the use of the international system of units (SI). NIST Special Publication 811, National Institute of Standards and Technology, Gaithersburg, USA, doi: 10.6028/NIST.SP.811e2008.

[10] ISO 80000-1 (2009). Quantities and units - Part 1: General, $1^{\text {st }}$ edition, International Organization for Standardization, Geneva, Switzerland.

[11] IEC 80000-13:2008 (2008). Quantities and units - Part 13: Information science and technology, International Organization for Standardization, Geneva, Switzerland.

[12] World Wide Web Consortium Extensible Markup Language (XML); version 1.0; $5^{\text {th }}$ edition, from $\underline{\text { https://www. }}$ w3.org/TR/xml/, accessed November 6, 2019.

[13] ISO 8601:2004 (2004). Data elements and interchange formats - Information interchange - Representation of dates and times, International Organization for Standardization, Geneva, Switzerland.

[14] RFC 3629 UTF-8 (2003). A transformation format of ISO 10464, https://tools.ietf.org/html/rfc3629, accessed November 10, 2019.

[15] PTB (2019). TraCIM service operated at PTB, from https://tracim.ptb.de, accessed November 29, 2019.

[16] IEC TS 62720:2017 (2017). Identification of units of measurements for computer-based processing, International Organization for Standardization, Geneva, Switzerland.

[17] JCGM 101:2008 (2008). Evaluation of measurement data - Supplement 1 to the "Guide to the expression of uncertainty in measurement" - Propagation of distributions using a Monte Carlo method, $1^{\text {st }}$ edition, from https://www.bipm.org/utils/common/documents/jcgm/JCGM_101_2008_E.pdff accessed October 5, 2019.

[18] JCGM 102:2011 (2011). Evaluation of measurement data - Supplement 2 to the "Guide to the expression of uncertainty in measurement" - Extension to any number of output quantities, from https://www.bipm.org/utils/common/documents/jcgm/JCGM_102_2011_E.pdf, accessed October 2019.

[19] Mohr, P. J., Newell, D. B., Taylor B. N. (2015). CODATA Recommended values of the fundamental physical constants: 2014, doi: 10.6028/NIST.SP.961r2015, accessed December 16, 2019.

[20] NIST (2018). CODATA Internationally recommended 2018 values of the fundamental physical constants, from http://physics.nist.gov/constants, accessed September 12, 2019.

[21] PTB (2019). Complete list of machine readable CODATA 2018 values, from https://ptb.de/si/codata/ m2m_constants_CODATA_2018_all_v2018.1.xml, accessed December 09, 2019.

[22] Hutzschenreuter, D., Härtig, F., Heeren, W., Wiedenhöfer, T., Forbes, A., Brown, C., Smith, I., Rhodes, S., Linkeová, I., Sýkora, J., Zelený, V., Ačko, B., Klobučar, R., Nikander, P., Elo, T., Mustapää, T., Kuosmanen, P., Maennel, O., Hovhannisyan, K., Müller, B., Heindorf, L., Paciello, V. (2019). SmartCom Digital System of Units (D-SI) Guide for the use of the metadata-format used in metrology for the easy-to-use, safe, harmonised and unambiguous digital transfer of metrological data, (Version D-SI 1.3), Zenodo, doi: 10.5281/zenodo.3522631, accessed November 21, 2019.

[23] Hutzschenreuter, D., Härtig, F., Wiedenhöfer, T., Smith, I., Brown, C. (2019). D-SI in short - Digital brochure on establishing the use of units in digitalised communication, Zenodo, doi: 10.5281/zenodo.3522074, accessed November 28, 2019.

[24] Hutzschenreuter, D., Härtig, F., Wiedenhöfer, T., Hackel, S.-G., Scheibner, A., Smith, I., Brown, C., Heeren, W. (2019). SmartCom Digital-SI (D-SI) XML exchange format for metrological data version 1.3.0, doi: 10.5281/zenodo.3366902, accessed October 24, 2019.

[25] Wright, J. (2019). siunitx - A comprehensive (SI) units package, Version v2.7t, from http://mirrors.ctan.org/macros/latex/contrib/siunitx/siunitx.pdf, accessed November 3, 2019.

[26] SIST EN ISO/IEC 17025:2017 (2017). General requirements for the competence of testing and calibration laboratories, Slovenski inštitut za standardizacijo (Slovenian Institute for Standardization), Ljubljana, Slovenia.

[27] Nikander, P., Elo, T., Mustapää, T., Kuosmanen, P., Hovhannisyan, K., Maennel, O., Brown, C., Dawkins, J., Rhodes, S., Smith, I., Hutzschenreuter, D., Weber, H., Heeren, W., Schönhals, S., Wiedenhöfer, T. (2020). Document specifying rules for the secure use of DCC covering legal aspects of metrology, doi: 10.5281/zenodo.3664211, accessed March 24, 2020.

[28] Regulation (EU) No 910/2014 of the European Parliament and of the Council of 23 July 2014 on electronic identification and trust services for electronic transactions in the international marked and repealing Directive 1999/93/EC (2014). Official journal of the European union, L 257, 73-115.

[29] Peters, D., Wetzlich, J., Thiel, F., Seifert, J.-P. (2018). Blockchain applications for legal metrology, In: Proseedings of 2018 IEEE International Instrumentation and Measurement Technology Conference (I2MTC), Houston, USA, doi: 10.1109/I2MTC.2018.8409668. 


\section{APEM}

Advances in Production Engineering \& Management Letnik 15 | Številka 1 | Marec 2020 | Strani 107-117
ISSN 1854-6250

Spletna stran: apem-journal.org Izvirni znanstveni članek

\title{
Komunikacija in validacija meroslovnih pametnih podatkov v loT-omrežjih
}

\author{
Ačko, B. ${ }^{a}{ }^{*}$, Weber, H. ${ }^{b}$, Hutzschenreuter, D. ${ }^{b}$, Smith, I. ${ }^{c}$ \\ ${ }^{a}$ University of Maribor, Faculty of Mechanical Engineering, Maribor, Slovenia \\ ${ }^{b}$ Physikalisch-Technische Bundesanstalt, Braunschweig, Germany \\ ${ }^{\mathrm{c}}$ National Physical Laboratory, Teddington, United Kingdom
}

\begin{abstract}
POVZETEK
Omrežje Internet of Things (IoT) omogoča komunikacijo podatkov znotraj omrežja in do podatkovnih vozlišč. Vendar pa je uporabnost podatkov odvisna od zmožnosti pravilne razlage le-teh. Za meroslovne podatke je učinkovita uporaba podatkov možna le, če so na voljo tudi številčna vrednost, pridružena enota in negotovost, izraženi v standardni obliki. Za razvoj, zagotavljanje in distribucijo formalnega okvira za prenos meroslovnih podatkov na podlagi Mednarodnega sistema enot je bil med Evropsko komisijo in Evropskim združenjem nacionalnih meroslovnih inštitutov (Euramet) dogovorjen evropski projekt EMPIR 17IND02 SmartCom. Namen projekta SmartCom je zagotoviti metodološko-tehnične temelje za nedvoumno, univerzalno, varno in enotno komunikacijo meroslovnih pametnih podatkov v IoT in Industriji 4.0. Projekt bo povečal industrijske zmogljivosti in zagotovil predpise za izmenjavo podatkov v IoT. Prav tako bo pomagal državam znotraj Evropske unije (EU) in državam s pridružitvenim sporazumom z EU pri razvoju izdelkov, ki so sposobni komunicirati v okoljih interneta stvari po vsem svetu. Ta članek poleg opisov splošnih idej in ciljev projekta predstavlja rezultate raziskave, dosežene v prvem vmesnem obdobju.
\end{abstract}

(c) 2020 CPE, University of Maribor. All rights reserved.
PODATKI O ČLANKU

Ključne besede:

Meroslovje;

Metapodatki o meritvah;

Informacijska in komunikacijska

tehnologija (IKT);

Pametni podatki;

Podatkovna komunikacija;

IoT-komunikacija;

IoT-mreženje;

Digitalno potrdilo o kalibraciji

*Kontaktna oseba:

bojan.acko@um.si

(Ačko, B.)

Zgodovina članka:

Prejet 27. decembra 2019

Popravljen 26. marca 2020

Sprejet 28. marca 2020 